\title{
Calling things by their name: Anand rejuvenates the Mahá-Bhárat
}

\author{
by R.C.S \\ P.I. Neuwegein
}

\begin{abstract}
R.C.S., one of the editors of P.I. Nieuwegein's newsletter, gives an overview of the work of a fellow prisoner in the jail, which consists of the translation and adaptation to modern times of the Mahá-Bhárat. This is a notable achievement in this prison's environment and will be of interest to other prisoners and prison educators who might want to draw comparisons, conclusions, and other ideas about it.
\end{abstract}

\section{Key words: Prison education; Mahá-Bhárat}

I am always keen to write about the most accomplished and brilliant initiatives carried out by our fellow detainees, and the work outlined in this article is one of the most inspiring. After getting to know Anand, I decided immediately his work needed to be known by everyone in the prison system because it is an extraordinary success story. Before starting his sentence Anand had no prior interest in Hindu mythology but while reading the Mahabbarata in jail it became the focus of his life. "It's Mahá-Bhárat', not Mahabbarata!" he explains. "People read corrected versions that have been translated from Sanskrit into English and they all make the mistake of misspelling most of the names in the book. I want this to change so that we can start calling everyone in the saga in the proper ways." And that is only the beginning of the project.

Anand is a Hindu from Surinam, and he surely knows his Mahá-Bhárat inside out. He has become one of the greatest experts in the epical Indian masterpiece in the Netherlands so it may come as a surprise to find him serving time in the Nieuwegein Penitentiary. But while there, he has undertaken a "Magna Opus" that is every bit as massive and as challenging as the original Mahá-Bhárat. Anand is translating it into Dutch. And not only that, he is doing it in everyday language so it is understandable by all, adding footnotes and comments, including a introduction that is a book by itself, "sideways exploring" the Bhagavad Gita and finding suitable illustrations, maps and other references. The end result will be a 5000+ page, 18 book collection that will shape the way that the Mahá-Bhárat is understood by the Dutch speaking community. Scholars, seculars and buffs alike will at last have the final weapon to gain the best insight into Hindu culture and that is no mean feat.

The Mahá-Bhárat came to Anand by chance while serving his long sentence. "It was not something that was intended at first. I have a Hindu background and the initial curiosity turned me back into re-reading the book. It was then when I discovered that there were many inconsistencies, lots of mistakes, and that everything, from the names to some of the situations, were poorly redacted or even not understandable. We have to see things in perspective; the book is extremely long and old, in some versions with more than 5000 pages written more than 5000 years ago in a 1000 year span. We, in Europe, work primarily with Sanskrit and English translations edited in Victorian times. It is bound to be inconsistent". This situation triggered something in him, and from that moment he knew what he wanted to do. "I thought I could make a better translation into Dutch, one that could sort out most of those inconsistencies, and retain all its core values while at the same time making it easier to read and more understandable in today's prose. Since then I haven't looked back. The

\footnotetext{
${ }^{1}$ A Sanskrit epic poem of ancient India. It is an important source of information on the development of Hinduisn between 400 bce and 200 ce and is regarded as both a religious text about dharma (Hindu moral law) and a history. It is the longest epic poem ever written, with over 200,000 individual verse lines and long prose passages. About 1.8 million words in total, the Mahá-Bhárat is roughly ten times the length of the Iliad and the Odyssey combined.
} 
Mahá-Bhárat is hugely challenging, but I can see in the book answers to many of life's situations, I can see in the book wise words of advice. It reflects so many of our history as a human society it never ceases to surprise me."

The scale of the project is daunting. It is measured in years and volumes, and Anand's life now practically revolves around it. "I work every day, for many hours, and I enjoy every minute of it. In my cell when I have to be inside and in the Education Department all the other times and where I even have a dedicated computer. I am now working on the introduction, which has taken me more than a year to complete, and on four of the 18 volumes. You should expect at least another ten years before most of the text is ready. Until then the Mahá-Bhárat will be very much in the centre of my life". Certainly, this means that we are looking at a life project to be continued when he is released and he already has plans; "I want to dig deeper into Hindu traditions and culture. I see myself working and helping in my local temple, and putting my experience in the Mahá-Bhárat at the service of the community and the scholars."

Anand faces other challenges too because publishing his work will be a big task in itself. He knows that to reach the maximum amount of Dutch readers he has to plan ahead with the times; "I think that the scale of the project means that I will have to release an electronic edition together with the standard paper one. Everything, from the fonts and spacing to the illustrations will be unique to my version. I am already looking at several publishing options with the help of my children, who by the way have always fully supported me. Besides, I am also looking forward to a prior release because I am working on a special introduction to the book and its characters as a standalone volume and that may happen sooner than I expected."

The Mahá-Bhárat has given a purpose to Anand's time spent in prison. "I was a very busy man outside, and I needed to have something to do in prison that made sense so that I would not go with the normal prison flow and fade away. This project has balanced me and at the same time given me the strength that is helping me in getting through this prison time. I can't conceive my life anymore without the Mahá-Bhárat; it has been a life changing experience. This also shows that reintegration is not limited to the usual prison options that you have to find your own way. There is nothing wrong with being a singularity; we can all find something that motivates us even if that something is not in the trodden path."

The project has had full support of the prison education team in Nieuwegein. "From the beginning I have had all the help from them and from the prison staff. I need a lot of extra research, books and media and I have never had any problem in getting them", says Anand. All the teachers help him and serve as "proof readers". Anand is not satisfied if when they are reading they do not completely understand every chapter, and countless hours are spent sometime in a triple translation effort, with parts in English that have to be doubly filtered before they can be deemed to be fit for purpose. He is also setting an excellent example for other inmates because his effort proves that the importance of prison education and support should not be limited to the standard offerings; and that big things can be accomplished even in the harshest environments.

I would like to give the final word to Anand: "We should always remember that things are not always what you think. For example, in the Mahá-Bhárat, the character of Karan is universally thought to be the bad guy. But, he is not. This surprised me at the beginning but now it has shed a whole different light in the way I see the book, and I know I still have many surprises awaiting me. After all the end is very far away!"

R.C.S. serves as an editor of P.I Neuwegein's newsletter at P.I. Neuwegein, a 480 cell capacity male Prison and Correctional Facility located in Nieuwegein, Netherlands.

Annet Bakker is the chairperson of the European Prison Education Association. 